Review

\title{
Extracellular zinc and ATP-gated P2X receptor calcium entry channels: New zinc receptors as physiological sensors and therapeutic targets
}

\author{
Erik M. Schwiebert ${ }^{1,2,3,4}$, Lihua Liang ${ }^{1,3}$, Nai-Lin Cheng ${ }^{1,3}$, Clintoria Richards Williams ${ }^{1}$, Dragos Olteanu ${ }^{1,4}$, \\ Elisabeth A. Welty ${ }^{1,3}$ \& Akos Zsembery ${ }^{1,3,5}$ \\ ${ }^{1}$ Department of Physiology and Biophysics, University of Alabama at Birmingham, Birmingham, Alabama, USA; \\ ${ }^{2}$ Department of Cell Biology, University of Alabama at Birmingham, Birmingham, Alabama, USA; ${ }^{3}$ Gregory Fleming \\ James Cystic Fibrosis Research Center, University of Alabama at Birmingham, Birmingham, Alabama, USA; ${ }^{4}$ Recessive \\ Polycystic Kidney Disease Core Center, University of Alabama at Birmingham, Birmingham, Alabama, USA; ${ }^{5}$ Present \\ address: Institute of Human Physiology and Clinical Experimental Research, Semmelweis University, Budapest, Hungary
}

Received 5 April 2005; accepted in revised form 8 July 2005

Key words: $\beta$ cells, calcium, cystic fibrosis, diabetes, epithelia, $\mathrm{P} 2 \mathrm{X}$ receptors, polycystic kidney disease, sensors, zinc

\begin{abstract}
In this review, we focus on two attributes of $\mathrm{P} 2 \mathrm{X}$ receptor channel function, one essential and one novel. First, we propose that $\mathrm{P} 2 \mathrm{X}$ receptors are extracellular sensors as well as receptors and ion channels. In particular, the large extracellular domain (that comprises $70 \%$ of the molecular mass of the receptor channel protein) lends itself to be a cellular sensor. Moreover, its exquisite sensitivity to extracellular $\mathrm{pH}$, ionic strength, and multiple ligands evokes the function of a sensor. Second, we propose that P2X receptors are extracellular zinc receptors as well as receptors for nucleotides. We provide novel data in multiple publications and illustrative data in this invited review to suggest that zinc triggers ATP-independent activation of P2X receptor channel function. In this light, P2X receptors are the cellular site of integration between autocrine and paracrine zinc signaling and autocrine and paracrine purinergic signaling. $\mathrm{P} 2 \mathrm{X}$ receptors may sense changes in these ligands as well as in extracellular $\mathrm{pH}$ and ionic strength and transduce these sensations via calcium and/or sodium entry and changes in membrane potential.
\end{abstract}

Abbreviations: ADP - adenosine diphosphate; ASIC - acid-sensing ion channels; ATP - adenosine $5^{\prime}$-triphosphate; $\mathrm{Ca}^{2+}-$ calcium; CF - cystic fibrosis; CFTR - cystic fibrosis transmembrane conductance regulator; $\mathrm{Cl}^{-}$- chloride; COPD - chronic obstructive pulmonary diseases; DEG-degenerin channels; DRASIC-ASIC from Drosophila; ENaC-epithelial $\mathrm{Na}^{+}$ channel; FDA - US Food and Drug Administration; G protein - heterotrimeric GTP-binding protein; GPCR - G proteincoupled receptor; $\mathrm{H}^{+}$- proton; IP3 - inositol trisphosphate; K(ATP) - ATP-regulated $\mathrm{K}^{+}$channel of sulfonylurea transporters and inwardly rectifying $\mathrm{K}^{+}$channels; $\mathrm{K}^{+}$- potassium; MDCK - Madin-Darby canine kidney cells; $\mathrm{Mg}^{2+}-$ magnesium; $\mathrm{Na}^{+}$-sodium; NMDG-N-methyl-D-glucamine; OTC-over-the-counter; P2X-purinergic receptor channel subfamily; PKD - polycystic kidney disease; PLC-phospholipase C; ppk-pickpocket from Drosophila; rpk-ripped pocket from Drosophila; TRP - Transient receptor potential channels; ZAC-zinc-activated channel; Zip-zinc influx protein transporters; $\mathrm{Zn}^{2+}$ - zinc; $\mathrm{ZnT}$ - zinc loading or efflux transporter

\section{Introduction}

Our laboratory has reviewed ATP release biology recently $[1,2]$. In this mini-review and based upon Symposium and poster presentations at Purines 2004, we wish to focus on the idea that $\mathrm{P} 2 \mathrm{X}$ receptor channels are extracellular sensors for cells that express them [3, 4]. In particular, they may be sensors for ATP, zinc, protons, and cations in

Correspondence to: Dr Erik M. Schwiebert PhD, Department of Physiology and Biophysics, Center University of Alabama at Birmingham, Birmingham, AL 35294-0005, USA. Tel: +1-205-9346234; Fax: +1-2059341445; E-mail: eschwiebert@physiology.uab.edu purinergic microenvironments bathing cells and occurring within tissues where extracellular autocrine and paracrine ATP and/or zinc signaling is critical and, arguably, most robust. In such microenvironments, diffusion distance is short, volume is minute, and/or ionic and $\mathrm{pH}$ composition is ideal. For a P2X sensor for zinc, ATP, protons, and cations to be relevant physiologically, these ligands must bind to this sensor within a microenvironment, because ATP is degraded rapidly and zinc is chelated by buffering proteins.

Derived from the "extracellular sensor" hypothesis for $\mathrm{P} 2 \mathrm{X}$ receptor channel function, we wish to introduce the concept that $\mathrm{P} 2 \mathrm{X}$ receptor channels may also be viable and 
important receptors for the essential micronutrient biometal and trace element, zinc. Zinc is a well-described co-agonist for specific $\mathrm{P} 2 \mathrm{X}$ receptor subtypes, $\mathrm{P} 2 \mathrm{X}_{2}, \mathrm{P} 2 \mathrm{X}_{3}$, and $\mathrm{P} 2 \mathrm{X}_{4}$ in particular. $\mathrm{P}_{2} \mathrm{X}_{5}$ and $\mathrm{P} 2 \mathrm{X}_{6}$ may also bind zinc as a coligand; however, the function of these two particular subtypes has been difficult to evaluate. Receptors for zinc have been postulated for many years [3-6]. Zinc receptors are likely not limited to a subset of $\mathrm{P} 2 \mathrm{X}$ receptor channels but may also comprise a family of zinc-sensing $\mathrm{G}$ proteincoupled receptors [4-6]. Here, we highlight recent published evidence that zinc is a full agonist for epithelial P2X receptors independent of ATP [4, 7]. We also have published evidence that extracellular zinc alone can mobilize $\mathrm{Ca}^{2+}$ release from intracellular stores [4], suggesting a second type of zinc membrane receptor coupled to intracellular signaling effectors. We hope that this review will shed light on a new sub-field of extracellular purinergic signaling that integrates with a rapidly emerging field of extracellular zinc signaling.

\section{A new view of $\mathrm{P} 2 \mathrm{X}$ receptor channels as extracellular sensors}

The family of $\mathrm{P} 2 \mathrm{X}$ receptor channels and their properties was reviewed elegantly and recently by North [8]. We do not wish to be repetitive to this seminal contribution. Rather, we wish to focus on the idea that the large extracellular domain for $\mathrm{P} 2 \mathrm{X}$ receptors acts as a sensor on the cell surface for multiple and different extracellular substances. This extracellular domain comprises approximately $70 \%$ of the molecular mass of $\mathrm{P} 2 \mathrm{X}$ receptor channel proteins. This extracellular domain provides the binding pocket for the nucleotide as well as a binding site or sites for zinc. In $\mathrm{P}_{2} \mathrm{X}_{2}$ through $\mathrm{P}_{2} \mathrm{X}_{4}$ (and, possibly, for $\mathrm{P} 2 \mathrm{X}_{6}$ ), zinc acts as an agonist [8]. In $\mathrm{P} 2 \mathrm{X}_{1}$ and $\mathrm{P} 2 \mathrm{X}_{7}$, zinc is an antagonist [8]. Extracellular $\mathrm{pH}$ also governs $\mathrm{P} 2 \mathrm{X}$ receptor function [8]. As such, there are thought to be one or more sites for proton $\left(\mathrm{H}^{+}\right)$binding within the extracellular domain of the receptor channel [8]. We hypothesize currently that external $\mathrm{pH}$ may govern zinc and ATP binding to the extracellular domain. As a cation-permeable channel, multiple binding sites for calcium $\left(\mathrm{Ca}^{2+}\right)$ and sodium $\left(\mathrm{Na}^{+}\right)$likely also exist to facilitate cation permeation through the extracellular domain and the channel pore [8]. With multiple binding sites for so many different extracellular constituents, the $\mathrm{P} 2 \mathrm{X}$ receptor extracellular domain will be fascinating to visualize in the coming years when a crystal structure emerges.

Meanwhile, our laboratory continues to draw topological analogies between P2X receptor channels and the degenerins (DEG)/epithelial $\mathrm{Na}^{+}$channel or ENaC superfamily $[1,8-13]$. The ENaC superfamily includes the ENaC gene family, the degenerin genes/proteins from $C$. elegans, the ripped pocket (rpk) and pickpocket (ppk) genes/proteins from Drosophila, the acid-sensing ion channels (ASICs, DRASIC), and the brain $\mathrm{NaC}$ channels (BNaCs) [8-13]. Despite the fact that there is no nucleotide or amino acid sequence homology, they possess a topology similar to
P2XRs (see Figure 1 below). In particular, each family has a large extracellular domain that represents $70 \%$ of the molecular mass of the polypeptide. All P2XRs, ENaCs, and $\mathrm{ENaC}$ relatives possess an even number of extracellular cysteine residues that may participate in similar intrachain disulfide bonding to provide critical three-dimensional structure to this domain. For example, all subunits of $\mathrm{ENaCs}, \alpha-, \beta-, \gamma-$, and $\delta$-ENaC, have 14 conserved cysteines in their extracellular domain and all ASIC subtypes have 12 conserved cysteines. Each P2XR subtype has 10 . The even number of conserved cysteines suggests that all extracellular cysteines may participate in intrachain disulfide bonding and confer an elaborate three-dimensional structure on the extracellular domain.

However, they could also participate in zinc binding under certain conditions. Indeed, histidines and cysteines comprise zinc-binding domains in zinc fingers and other related domains. Although analysis by our laboratory indicates that bona fide zinc fingers are not present in P2XRs, histidines cluster within the cysteine-rich regions of P2XR extracellular domains and may collaborate to confer a zinc finger-like binding domain, especially in a three-dimensional manner not yet visualized. Recent work by Ennion and Evans indicated that all 10 cysteine residues in the extracellular loop of the $\mathrm{P}_{2} \mathrm{X}_{1}$ receptor are thought to participate in disulfide bridging [14]. Five disulfide bonds were formed. C117-C165, C126-C149, and C132-C159 were formed in the first cysteine-rich region, while C217227 and C261-C270 were formed in the second cysteinerich region [14]. They also indicated that none of these bonds are individually essential for channel function, but the disruption of the C261-C270 bond and C117-C165 bond affected trafficking to the plasma membrane. The

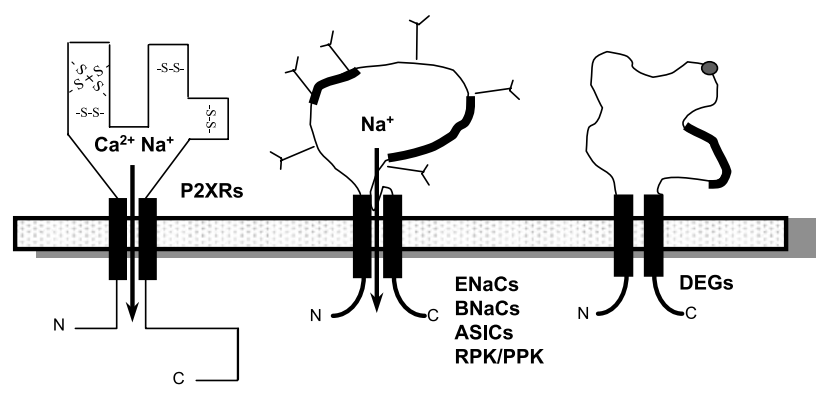

P2XRs...Extracellular zinc and ATP sensing; Proton and cation sensing

ENaCs...Extracellular cation sensing; Mechanosensitive; Zinc sensitive

BNaCs...Extracellular cation sensing; Proton and zinc-sensitive

ASICs...Extracellular proton sensing; Mechanosensitive; Zinc-sensitive

RPK/PPK...Mechanosensitive in the fly; Chemosensitive?

DEGs...Mechanosensitive in the worm; Chemosensitive?

Figure 1. Cartoon of the topology of P2XRs and cation channels of the ENaC superfamily. P2XRs are a member of the two transmembranespanning cation channel superfamily that includes amiloride-sensitive $\mathrm{ENaC}$ sodium channels and $\mathrm{ENaC}$ relatives in neurons (BNaCs, ASICs, DEGs, RPK, and PPK). Below the cartoons are listed the demonstrated or postulated sensory roles for these related cation channels within this superfamily. 
same analysis was done with extracellular cysteines for $\mathrm{P} 2 \mathrm{X}_{2}$ by Hume and colleagues [15]. They also found evidence for disulfide bridges between pairs of cysteine residues that are conserved between $\mathrm{P} 2 \mathrm{X}_{1}, \mathrm{P} 2 \mathrm{X}_{2}$, and all other subtypes. They also saw some effects on zinc potentiation, suggesting that cysteines might contribute structure to a zinc binding site [15]. They also could not assign all cysteines to disulfide bridges, suggesting that some may be free to participate in other reactions. A more recent paper by Hume and coworkers showed that zinc binding may involve cysteines across separate subunits within a multimer [16]. As such, the zinc binding site may lie within a pocket contributed by multiple extracellular domains within a multimer [16]. Taken together, this disulfide bridging could be dynamic, freeing up these residues for zinc binding under certain conditions. Proper topology and glycosylation of the P2XRs may indeed be critical for proper ER processing and trafficking through the secretory pathway. Examination of extracellular domain cysteines and histidines clustered within the cysteine-rich regions will be critical to assess zinc binding to specific P2XRs in the coming years.

The same can be postulated for the ENaC superfamily, although the exact nature of the intra-chain disulfide bonding between extracellular cysteines may differ and the threedimensional structure may as well. However, the concept of the ENaC superfamily as extracellular sensors has been postulated. Extracellular protons $\left(\mathrm{H}^{+}\right)$gate the ASICs [17]. Their name, the acid-sensing ion channels, was well thought [17]. Lazdunski and colleagues have shown elegantly that zinc can potentiate acid gating of the ASICs [17]. Extracellular $\mathrm{H}^{+}$and zinc also synergistically potentiate $\mathrm{BNaC}$ function $[18,19]$. Recent studies by Driscoll's group has shown that some of the degenerin channels are permeable to calcium [20], making them putative calcium entry channels in the worm. Extracellular $\mathrm{H}^{+}$and acidic external $\mathrm{pH}$ activate the most recently cloned $\mathrm{ENaC}$ sub- unit, $\delta$-ENaC [21]. Human $\delta$-ENaC is potentiated dramatically in its function at $\mathrm{pH}$ 5.0. A mouse ortholog has not bee found yet; however, this subunit may confer acid sensing upon $\mathrm{ENaC}$ heteromultimers in certain microenvironments. Taken together, these seminal papers and reviews have shed light on this $\mathrm{DEG} / \mathrm{ENaC}$ superfamily as being critically involved in touch, temperature, mechanical, $\mathrm{pH}$ and other sensory mechanisms. It is likely that they are sensors too.

Members of the ENaC superfamily have been implicated as mechanical sensors, especially $\mathrm{ENaC}$ relatives in $C$. elegans and Drosophila [9-13]. ENaC itself as well and the DEG channels have been shown to be modulated by membrane stretch by Benos and colleagues among others [22-25]. Although zinc is a ligand for some members of the ENaC superfamily, a bona fide endogenous ligand for members of the ENaC superfamily remains elusive. Our laboratory hypothesizes that $\mathrm{ENaC}$ and $\mathrm{ENaC}$ relatives likely bind an endogenous ligand that has yet to be elucidated. A current cartoon of P2XRs, ENaC, mammalian $\mathrm{ENaC}$ relatives, and $\mathrm{ENaC}$ relatives from the worm and the fly are shown in Figure 1, along with current opinion and hypotheses about the sensory function of these two transmembrane-spanning cation channels within this unique extracellular domain.

\section{Epithelial P2X receptors are sensors for ATP, zinc, and cations}

Recent work performed by our laboratory suggests that $\mathrm{P} 2 \mathrm{X}$ receptor $\mathrm{Ca}^{2+}$ entry channel function is markedly sensitive to changes in external $\mathrm{H}^{+}$and $\mathrm{Na}^{+}$concentration and is gated by zinc alone, ATP alone, or both. A combination of zinc and ATP in micromolar concentrations potentiates $\mathrm{Ca}^{2+}$ entry through epithelial $\mathrm{P} 2 \mathrm{X}$ receptor channels $[3,4,7]$. The combination of ligands likely is optimal for

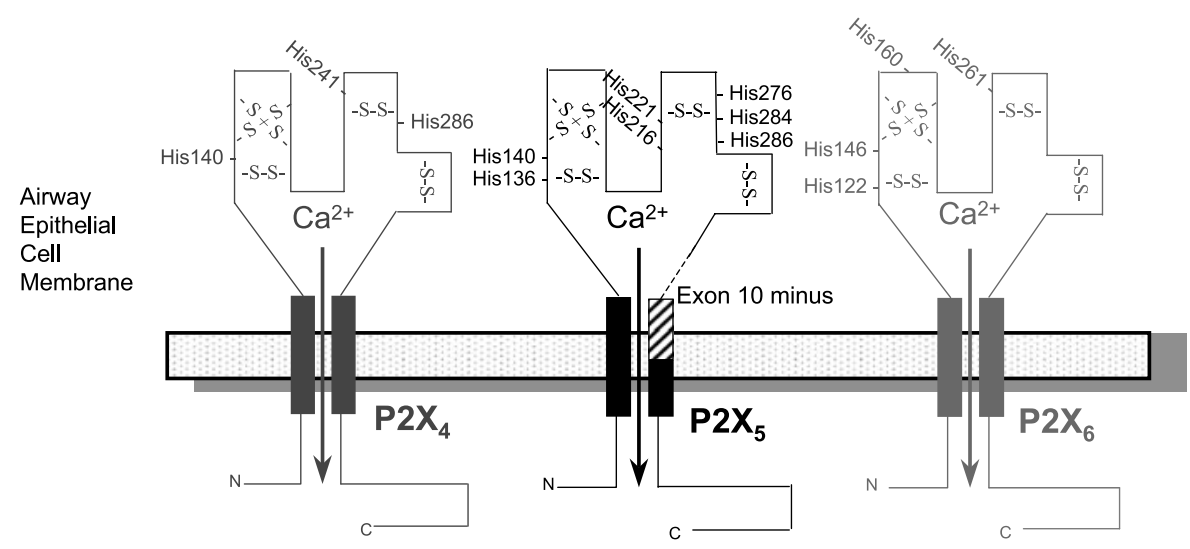

Figure 2. Epithelial $\mathrm{P} 2 \mathrm{X}_{4}$ and $\mathrm{P} 2 \mathrm{X}_{6}$ are the subtypes that are likely stimulated by zinc in our experimental conditions. Extracellular histidines are shown for the three subtypes shown to be expressed in epithelia at the mRNA and protein level. We believe that an alkaline $\mathrm{pH}$ deprotonates these histidines allowing zinc to bind with higher affinity. We also believe that removal of $\mathrm{Na}^{+}$abolishes its competition with $\mathrm{Ca}^{2+}$ for the channel pore and that it also unmasks histidines within the cysteine-rich domains for better zinc binding. 
gating of $\mathrm{P} 2 \mathrm{X}$ receptor channel activity. RNA and protein expression studies in epithelial and endothelial cell models from many different tissues showed shared expression of $\mathrm{P} 2 \mathrm{X}_{4}, \mathrm{P} 2 \mathrm{X}_{5}$, and $\mathrm{P} 2 \mathrm{X}_{6}$. These critical epithelial and endothelial P2XR subtypes are illustrated in Figure 2 with the sites of cysteines reflected by putative disulfide bridges and the sites of histidines shown. More recent siRNA analysis showed recently that $\mathrm{P} 2 \mathrm{X}_{4}$ and $\mathrm{P} 2 \mathrm{X}_{6}$ collaborate to confer extracellular zinc-induced $\mathrm{Ca}^{2+}$ entry independent of $\mathrm{P}_{2} \mathrm{X}_{5}$. We have not ruled out the possibility that $\mathrm{P} 2 \mathrm{X}_{5}$ may confer ligand-induced effects on a heteromultimeric complex of epithelial P2X receptor channels without conducting $\mathrm{Ca}^{2+}$ itself. P2X receptor subtypes are known to form homomultimers or heteromultimers [8, 26, 27]. With the exception of $\mathrm{P}_{2} \mathrm{X}_{6}$ that may [28] or may not [8] form a receptor channel by itself, all other P2XR subtypes can co-assemble into homomultimers. Known heteromultimers include $\mathrm{P} 2 \mathrm{X}_{1 / 5}, \mathrm{P} 2 \mathrm{X}_{2 / 3}, \mathrm{P} 2 \mathrm{X}_{2 / 6}$ and $\mathrm{P} 2 \mathrm{X}_{4 / 6}$ [8]. Other heteromultimers are likely to emerge [5]. It is important to note that $\mathrm{P} 2 \mathrm{X}_{6}$ is an important modulatory subtype for other $\mathrm{P} 2 \mathrm{X}$ receptor subtypes. Nevertheless, recently, glycosylated $\mathrm{P}^{2} \mathrm{X}_{6}$ was shown to form a high affinity ATP-gated cation channel, while non-glycosylated $\mathrm{P}_{2} \mathrm{X}_{6}$ does not [28]. We now hypothesize that it plays a special modulatory role for $\mathrm{P} 2 \mathrm{X}_{4}$ in airway and other epithelial cell biology. We intend to focus on the role of these wild-type epithelial P2X receptor channel subtypes in the coming years.

This $\mathrm{P} 2 \mathrm{X}$ receptor-mediated $\mathrm{Ca}^{2+}$ entry in airway and other epithelia is more optimal when the extracellular saline or Ringers is modified to dysinhibit $\mathrm{Ca}^{2+}$ movement through the $\mathrm{Ca}^{2+}$-permeable non-selective cation channel pore of $\mathrm{P} 2 \mathrm{X}$ purinergic receptor channels. Most $\mathrm{Ca}^{2+}$ entry channels are, by definition, $\mathrm{Ca}^{2+}$-permeable non-selective cation channels that mediate $\mathrm{Na}^{+}$influx as well as $\mathrm{Ca}^{2+}$ entry down a favorable chemical concentration gradient into the cell [29-33]. Despite a favorable permeability ratio for $\mathrm{Ca}^{2+}$ over $\mathrm{Na}^{+}, \mathrm{Na}^{+}$is $140 \mathrm{mM}$ in normal Ringer or plasma while $\mathrm{Ca}^{2+}$ is $1-2 \mathrm{mM}$. $\mathrm{Na}^{+}$will, thus, always win this competition with $\mathrm{Ca}^{2+}$. Potassium $\left(\mathrm{K}^{+}\right)$can move in the opposite direction (e.g., out of the cell) down its favorable gradient through $\mathrm{P} 2 \mathrm{X}$ receptor channels. This permeability of P2X receptor channels may also have critical physiological implications that are yet to be appreciated.

When we replaced $\mathrm{Na}^{+}$with an impermeant cation in the extracellular saline vehicle such as $N$-methyl-D-glucamine (NMDG) or Tris, the sustained nature or 'plateau' of the $\mathrm{Ca}^{2+}$ entry signal triggered by zinc and ATP was augmented in human airway epithelial cells [3, 4, 7]. Figure 3 shows the effect of combining all of these modifications of the $\mathrm{Ca}^{2+}$ signal in original data not included in our recent publication [4]. The same effects have been observed in model epithelia as well as non-epithelial cell models from other tissues (EM Schwiebert, unpublished observations). Modulation of $\mathrm{H}^{+}$concentration or $\mathrm{pH}$ in the extracellular saline vehicle was also crucial to the magnitude and sustained nature of the epithelial $\mathrm{P} 2 \mathrm{X}$ receptor-mediated $\mathrm{Ca}^{2+}$ entry signal (Figure 3A). While most $\mathrm{P} 2 \mathrm{X}$ receptor subtypes are stimulated or inhibited by external acidic $\mathrm{pH}$, epithelial $\mathrm{P} 2 \mathrm{X}$ receptor stimulation by extracellular zinc and ATP was potentiated markedly by a mild external alkaline $\mathrm{pH}$ of 7.9. External $\mathrm{pH}$ values of 7.9 or higher potentiated zinc and ATP gating of $\mathrm{P} 2 \mathrm{X}$ receptor $\mathrm{Ca}^{2+}$ entry channels markedly in airway epithelia. We postulate currently that external $\mathrm{Na}^{+}$and $\mathrm{H}^{+}$concentrations govern zinc and ATP binding to the extracellular domain of these epithelial P2X receptors. It is important to note that these saline vehicle conditions can be modified in the context of therapies for cystic fibrosis (CF) and other respiratory disorders where the agonists can be sprayed, nebulized or aerosolized in that modified vehicle. They could also be modified in topical solutions applied to the skin, eye, ear, etc. Therapeutic angles involving the targeting of zinc or zinc plus ATP to P2X receptors are addressed below.

\section{The $\mathrm{P} 2 \mathrm{X}$ receptor channel is not just an ATP receptor anymore}

\section{$P 2 X$ receptors are zinc receptors}

Our laboratory is exploiting the ability of the $\mathrm{P} 2 \mathrm{X}$ receptor channel to bind zinc as a full agonist for possible therapeutic importance in cystic fibrosis (CF) and other diseases. Sustained $\mathrm{Ca}^{2+}$ entry mediated by epithelial P2X receptor channels and stimulated by zinc and ATP was also mimicked by addition of zinc alone. In addition to the robust and sustained $\mathrm{Ca}^{2+}$ entry signal alluded to above, Figure $3 \mathrm{~A}$ also shows the experiment that made us realize that the $\mathrm{P} 2 \mathrm{X}$ receptor channel may be a zinc receptor. In an error in solution switching, ATP was washed away first instead of zinc. The sustained $\mathrm{Ca}^{2+}$ signal continued unabated in the presence of zinc alone. In Figure 3B, we show the sustained $\mathrm{Ca}^{2+}$ signal elicited with zinc alone in the presence of extracellular $\mathrm{Ca}^{2+}$. It is important to note that, in this and previous studies, all other possible routes of $\mathrm{Ca}^{2+}$ entry were ruled out through experimentation or from the literature [3, 4]. In Figure 3C, we show that zinc alone triggered a $\mathrm{Ca}^{2+}$ release from intracellular stores. We hypothesize currently that the sustained $\mathrm{Ca}^{2+}$ plateau or signal induced by extracellular zinc alone is a combination of opening epithelial P2X receptor channels and engaging zinc-sensing $G$ protein-coupled receptors. Study of these dual zinc receptors in epithelial and other cell models is in progress.

Nevertheless, we wanted to confirm that this was a zinc effect independent of the nucleotide on epithelial P2X receptor channels. We were well aware of flow- and mechanically induced ATP release and that it may be occurring in our flow-based fluorescence imaging system $[3,4,7]$. Further analysis of this zinc effect within a perfused fluorimeter system monitoring Fura-2/AM fluorescence showed that endogenous release of ATP was potentiating zinc effects. In Figure 3D, complete elimination of ATP and ADP with the ATP scavengers, hexokinase and apyrase, reduced but did not prevent zinc from triggering a robust and sustained $\mathrm{Ca}^{2+}$ entry signal (Figure 3D). The average increase in cell $\mathrm{Ca}^{2+}$ triggered by this dose of zinc salt is shown by the dashed line superimposed on this 
A

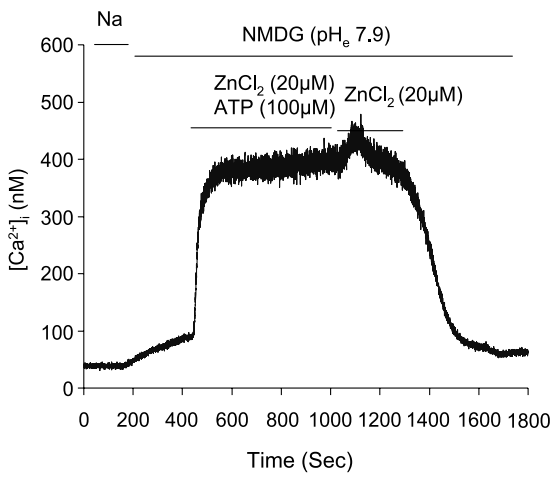

C

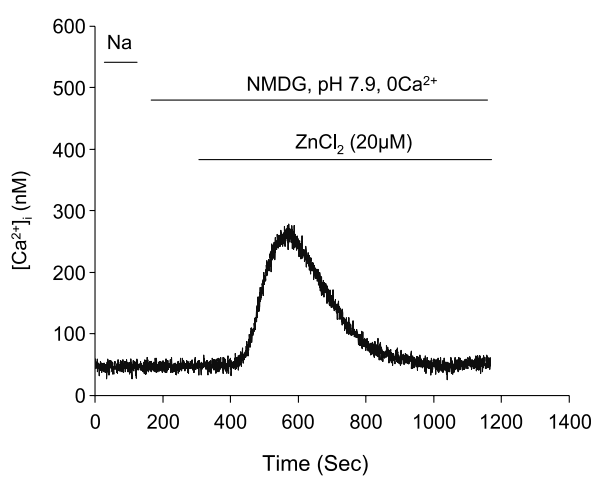

E Control

$* *$

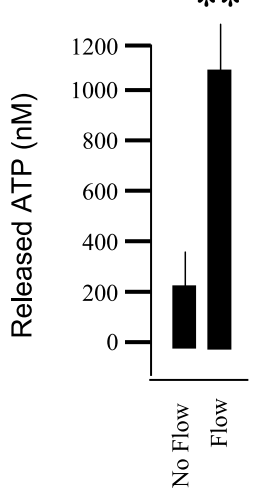

Hexokinase

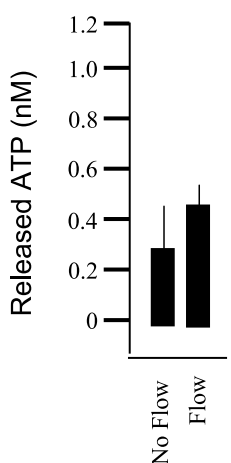

B

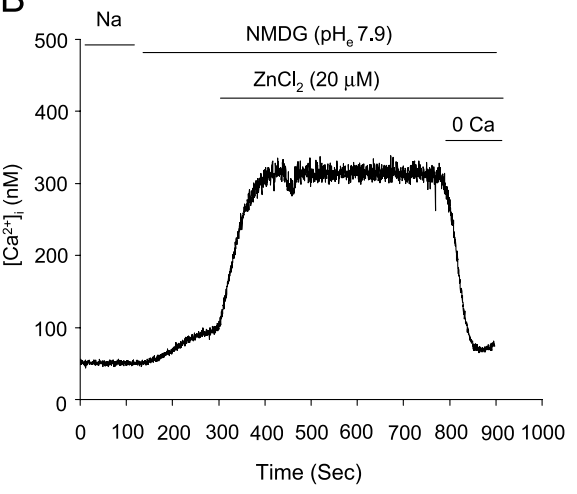

D Hexokinase $(5 \mathrm{U} / \mathrm{ml})+$ Apyrase $(1 \mathrm{U} / \mathrm{ml})$

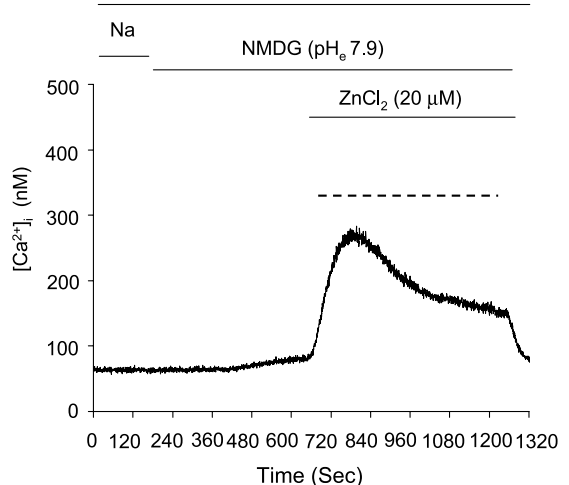

Apyrase Both Scavengers

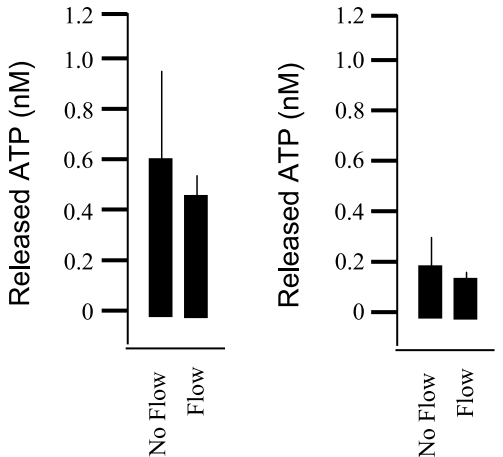

Figure 3. Potentiation of $\mathrm{Ca}^{2+}$ entry mediated by $\mathrm{P} 2 \mathrm{X}$ receptor channels by zinc alone. Confluent IB3-1 cystic fibrosis human airway epithelial cells grown on coverslips and inserted into a perfused cuvette within a fluorimeter were used for these experiments. Fluorescence from the entire confluent culture was measured. The effects of extracellular zinc are reproducible and consistent. The perfusion began with a standard Na-containing ringer. We then switched to a " $\mathrm{Ca}^{2+}$ entry Ringer" where Na was replaced with $N$-methyl-D-glucamine (NMDG), pH was modified to 7.9, $\left[\mathrm{Ca}^{2+}\right]$ was increased to $3 \mathrm{mM}$, and $\mathrm{Mg}^{2+}$ was omitted. Because these zinc receptors and responses on intact in CF airways cells and translate into rescue of $\mathrm{Cl}^{-}$secretion, we postulate that this is a viable signaling pathway to target with putative zinc-based therapeutic formulations. (A) This plot shows the key experiment in which ATP $(100 \mu \mathrm{M})$ was removed first in a way that was not intended. Zinc $(20 \mu \mathrm{M})$ remained in the perfusate and the sustained $\mathrm{Ca}^{2+}$ entry signal remained. Removal of zinc from the perfusate reversed the $\mathrm{Ca}^{2+}$ entry signal back to baseline, showing complete reversibility of zinc effects. (B) Because of this unexpected result from this unintended experiment (we had intended to remove zinc first in A), we assessed the effects of zinc alone in the perfusate independent of exogenously added ATP. Zinc elicited the same $\mathrm{Ca}^{2+}$ entry signal. In this case, zinc remained in the perfusate but we omitted $\mathrm{Ca}^{2+}$ from the solution and the $\mathrm{Ca}^{2+}$ entry signal was reversed completely. (C) Although the experiment in B suggested that extracellular zinc alone triggered marked $\mathrm{Ca}^{2+}$ entry from extracellular stores, we performed the requisite experiment of assessing zinc effects in the absence of extracellular $\mathrm{Ca}^{2+}$. To our surprise, extracellular zinc alone triggered a $\mathrm{Ca}^{2+}$ release from intracellular stores that was transient and reminiscent of thapsigargin-induced release from ER stores. (D) Despite the compelling results with zinc alone, we were aware that the flow of the perfusate might induce release of endogenous ATP into the system. As such, we assessed the effects of zinc in the presence of dual ATP scavengers, hexokinase $(5 \mathrm{U} / \mathrm{ml}$ with $5 \mathrm{mM}$ glucose) and apyrase $(1 \mathrm{U} / \mathrm{ml}$ ). The response to zinc was reduced but not eliminated, suggesting ATP-independent effects of zinc. (E) To quantify precisely the [ATP] concentration achieved by flow-induced release of endogenous ATP, we captured the perfusate under 'no flow' and "standard flow rate" conditions. Flow induced a release of ATP from the cells that was approximately $1 \mu \mathrm{M}$. Presence of either scavenger or both scavengers at the concentrations used eliminated circulating ATP from the system to a level at or below $1 \mathrm{nM}$ near the lower limit of detection with luciferase and luciferin-based methods [100]. Please note the dramatically different $Y$-axis scales with regard to [ATP] between these graphs. 
fluorescence trace (Figure 3D). To quantify the amount of ATP released in these perfused fluorimetry measurements within the cuvette that holds the confluent coverslip of CF human airway epithelial cells, we captured the solution in the cuvette in the absence of flow and the 'flow-through' at the standard perfusion rate used in our fluorescence studies. Interestingly, this flow stimulus augmented ATP release markedly to an estimated ATP concentration of slightly above $1 \mu \mathrm{M}$ (Figure 3E). Sampling in the presence of either hexokinase or apyrase at the concentrations used in the experiment with zinc in Figure 3D revealed a complete elimination of ATP in the system. Presence of both scavengers did the same. Values of released ATP in the presence of one or both scavengers were less that $1 \mathrm{nM}$ which is pushing the sensitivity of detection by luciferase/ luciferin-based methods. Taken together, these data and previous findings strongly suggest that zinc can engage and stimulate P2X receptors in an ATP-independent manner. We also postulate currently that zinc binding to the extracellular domain may increase the affinity of the extracellular domain for ATP to allow ATP to engage the receptor at a much lower dose. Nevertheless, our findings suggest that the biometal does not require ATP to engage the P2X receptor and open its channel.

\section{A second zinc receptor?}

Moreover, our data also revealed that zinc could trigger a $\mathrm{Ca}^{2+}$ transient derived from intracellular stores in the absence of extracellular $\mathrm{Ca}^{2+}$ (Figure 3C above). This $\mathrm{Ca}^{2+}$ transient induced by zinc in $0 \mathrm{Ca}^{2+}$ solutions was abolished by thapsigargin pretreatment and emptying of intracellular stores [4], suggesting that zinc may also engage a cell surface zinc receptor coupled to intracellular signal transduction effectors. Such a zinc-sensing $G$ protein-coupled receptor has been postulated for colonocytes and hepatocytes $[5,6]$. We are intrigued that such a receptor is also expressed in airway epithelia. We have not ruled out the possibility that extracellular zinc could engage calcium-sensing $\mathrm{G}$ protein-coupled receptors [34]. Such a possibility may be unlikely due to recent work showing that cadmium, zinc, and nickel engage a divalent cation sensing receptor with properties distinct from the calcium-sensing receptor [34]. This divalent cation-sensing receptor was found to be coupled to phospholipase $\mathrm{C}$ (PLC) and inositol trisphosphate $\left(\mathrm{IP}_{3}\right)$ [34]. A second divalent cation-sensing and $\mathrm{Ca}^{2+}$-mobilizing receptor mechanism triggered by zinc could also contribute to the sustained nature of the zinc-induced $\mathrm{Ca}^{2+}$ signal observed in airway epithelia. We also believe that zinc may enter the cell through zinc-specific transporters and modulate $\mathrm{Ca}^{2+}$ buffering mechanisms to potentiate the $\mathrm{Ca}^{2+}$ signal. One study suggests that intracellular $\mathrm{Zn}^{2+}$ inhibits plasma membrane $\mathrm{Ca}^{2+}$ ATPase pumps in a membrane vesicle preparation [35]. Nevertheless, removal of zinc leads to a complete reversal of the sustained $\mathrm{Ca}^{2+}$ plateau to baseline. Therefore, zinc does not affect all of the buffering mechanisms in the cell. This concept is addressed below in terms of therapeutic angles for zinc-based formulations.
We have reviewed past literature to determine whether P2X receptor channels were ever studied as biometal receptors independent of the nucleotide ligand. Although we have found a plethora of studies including assessment of copper and zinc competition as co-agonists [8,36], ATP or an ATP analog was always included in these and other experiments as the primary agonist. We currently view P2X receptors as zinc receptors and ATP receptors where each ligand can engage the receptor and open the channel independently as well as together. Indeed, the recent study defining an intrasubunit binding site for zinc among multiple $\mathrm{P} 2 \mathrm{X}_{2}$ receptor subunits [16] is compelling and supports our case as well as that of others.

\section{Exploiting the sensor properties and zinc gating of P2X receptor channels for putative therapies}

\section{Cystic fibrosis and other respiratory diseases}

Until now, therapeutic approaches with $\mathrm{Ca}^{2+}$ mobilizing agonists in CF have only yielded a transient increase in cytosolic free $\mathrm{Ca}^{2+}$ and a transient rescue of chloride $\left(\mathrm{Cl}^{-}\right)$ permeability or $\mathrm{Cl}^{-}$secretion [37,38]. Transient effects are insufficient in CF, because CFTR $\mathrm{Cl}^{-}$channels in non$\mathrm{CF}$ tissues are stimulated in a monophasic and sustained manner by cyclic nucleotides. As such, a therapeutic approach targeted at a naturally expressed receptor or channel must have a sustained effect. Moreover, this effect should also be reversible and re-acquirable (i.e., should show reversal and not show tachyphylaxis or inactivation). When we achieved a sustained $\mathrm{Ca}^{2+}$ signal with zinc alone or with zinc and ATP that ranged from 200 to $600 \mathrm{nM}$ above baseline in both non-CF and CF human airway epithelial cell models, we hypothesized that we could translate this sustained signal into a sustained rescue of $\mathrm{Cl}^{-}$ permeability in CF that rivaled CFTR activation in a normal cell. Such a sustained and marked $\mathrm{Ca}^{2+}$ signal was already shown to potentiate ciliary beat [39-41].

In two CF mouse models (and in another since), we achieved a sustained rescue of $\mathrm{Cl}^{-}$secretion in our ' $\mathrm{Ca}^{2+}$ entry Ringer' that was equivalent to or greater than that achieved by stimulation of CFTR $\mathrm{Cl}^{-}$channels by albuterol and adenosine, two complementary cyclic AMP mobilizing agonists [4]. $\mathrm{Cl}^{-}$permeability rescue was assessed in non-polarized CF human airway epithelial cells by an SPQ halide fluorescence assay in vitro, in polarized CF human and mouse airways epithelial cells in Ussing chambers in vitro, and in CF mouse nasal mucosa by an in vivo nasal potential difference assay [4]. We are currently defining any and all apical conductances that we may be stimulating with this sustained $\mathrm{Ca}^{2+}$ entry approach to rescue $\mathrm{Cl}^{-}$permeability and $\mathrm{Cl}^{-}$and water secretion. The proposed cellular mechanism of this rescue is shown in Figure 4.

The benefits of extracellular zinc and zinc-induced $\mathrm{Ca}^{2+}$ entry via $\mathrm{P} 2 \mathrm{X}$ receptor channels may not be limited to rescue of $\mathrm{Cl}^{-}$secretion. Potentiation of ciliary beat can only help in CF. Moreover, extracellular zinc may inhibit 


\section{Zinc benefits to CF lung therapy?}

- Rescue of $\mathrm{Cl}, \mathrm{HCO}_{3}$ and fluid secretion

- Attenuation of $\mathrm{Na}^{+}$hyperabsorption and $\mathrm{H}^{+}$conductance

- Potentiation of ATP-, $\mathrm{Na}^{+}$- and

$\mathrm{Ca}^{2+}$-dependent ciliary beat

- Anti-oxidant

- Anti-inflammatory

- Anti-viral

- Anti-bacterial

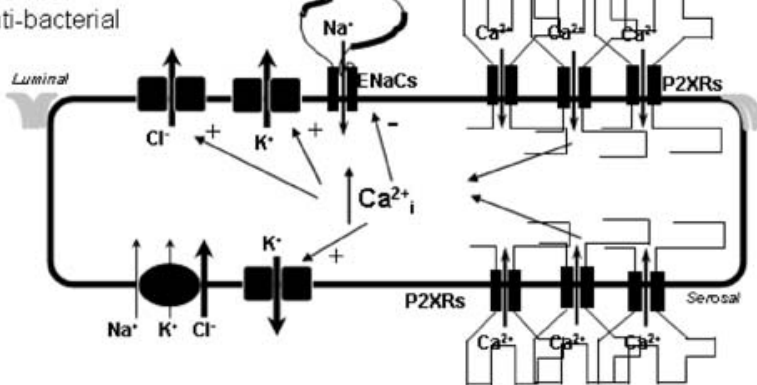

Figure 4. Possible therapeutic benefits of zinc-based fourmations for cystic fibrosis. Possible benefits of zinc are listed. Multiple CF defects could benefit by zinc binding to $\mathrm{P} 2 \mathrm{X}$ receptor channels on or from zinc entry into CF human airway epithelial cells (see Figure 6 for postulated benefits of zinc entry). An increase in $\mathrm{Ca}^{2+}$ induced by zinc at $\mathrm{P} 2 \mathrm{X}$ receptor or possible direct zinc inhibition would disable hyperactive $\mathrm{ENaC}$ channels. The sustained $\mathrm{Ca}^{2+}$ entry signal mediated by $\mathrm{P} 2 \mathrm{X}$ receptor channels would require $\mathrm{KCl}$ secretion and augment ciliary beat. The latter is not affected in CF; however, augmentation of ciliary beat can only help clear tenacious and dehydrated mucus.

hyperactive $\mathrm{ENaC}$ channel-mediated hyperabsorption of sodium directly (42 and D Olteanu, A Zsembery, and EM Schwiebert, unpublished observations). It is important to note that these data derived from epithelial cell systems differ from data garnered by Kleyman and coworkers in Xenopus oocytes overexpressing $\mathrm{ENaC}$ heteromultimers [43-45]. We believe that these are very different systems.
There is also disagreement within the Xenopus oocyte system, where Van Driessche and coworkers find zinc inhibition [42, 46] and Kleyman and colleagues find zinc potentiation by removal of $\mathrm{Na}^{+}$self-inhibition [43-45]. Or, the increase in cell $\mathrm{Ca}^{2+}$ mediated by $\mathrm{P} 2 \mathrm{X}$ receptors should attenuate upregulated $\mathrm{ENaC}$ in $\mathrm{CF}[9,10,20]$. This sustained $\mathrm{Ca}^{2+}$ signal would also open $\mathrm{Ca}^{2+}$ activated $\mathrm{K}^{+}$ channels that would augment $\mathrm{Cl}^{-}$secretion electrically in either or both membranes [47-52]. We are investigating these additional cellular mechanisms of possible therapeutic benefit for $\mathrm{CF}$ that could involve zinc-based formulations. These cellular mechanisms are also listed and/or shown in Figure 4.

Zinc is a cytoprotective biometal and a well-known antiinflammatory [53, 54]. Despite this known fact, the cellular and molecular mechanisms of action are ill-defined. Zinc salts are formulated within wound healing and skin creams and solutions as topical over-the-counter (OTC) homeopathic (5-10\% zinc salt formulations) and FDA-approved medicines $(0.1-0.25 \%$ zinc salt formulations) [55]. Zinc salts also have anti-viral and anti-bacterial properties [56-58]. Oral zinc supplementation of nutrition and diet has led to a reduction in the incidence and severity of multiple infectious diseases [59, 60]. Zinc salts also have anti-oxidant and anti-apoptotic properties [61]. The cellular and molecular mechanisms of these effects are only beginning to emerge. Figure 5 extends our hypotheses of these additional possible benefits of zinc action for $\mathrm{CF}$ therapy. CF also has upregulated neutrophil activation and transmigration and presents with chronic and recurrent bacterial infections [62]. As such, a zinc-based formulation might be therapeutic against these $\mathrm{CF}$ endpoints as well as a multitude of other respiratory diseases that include com-

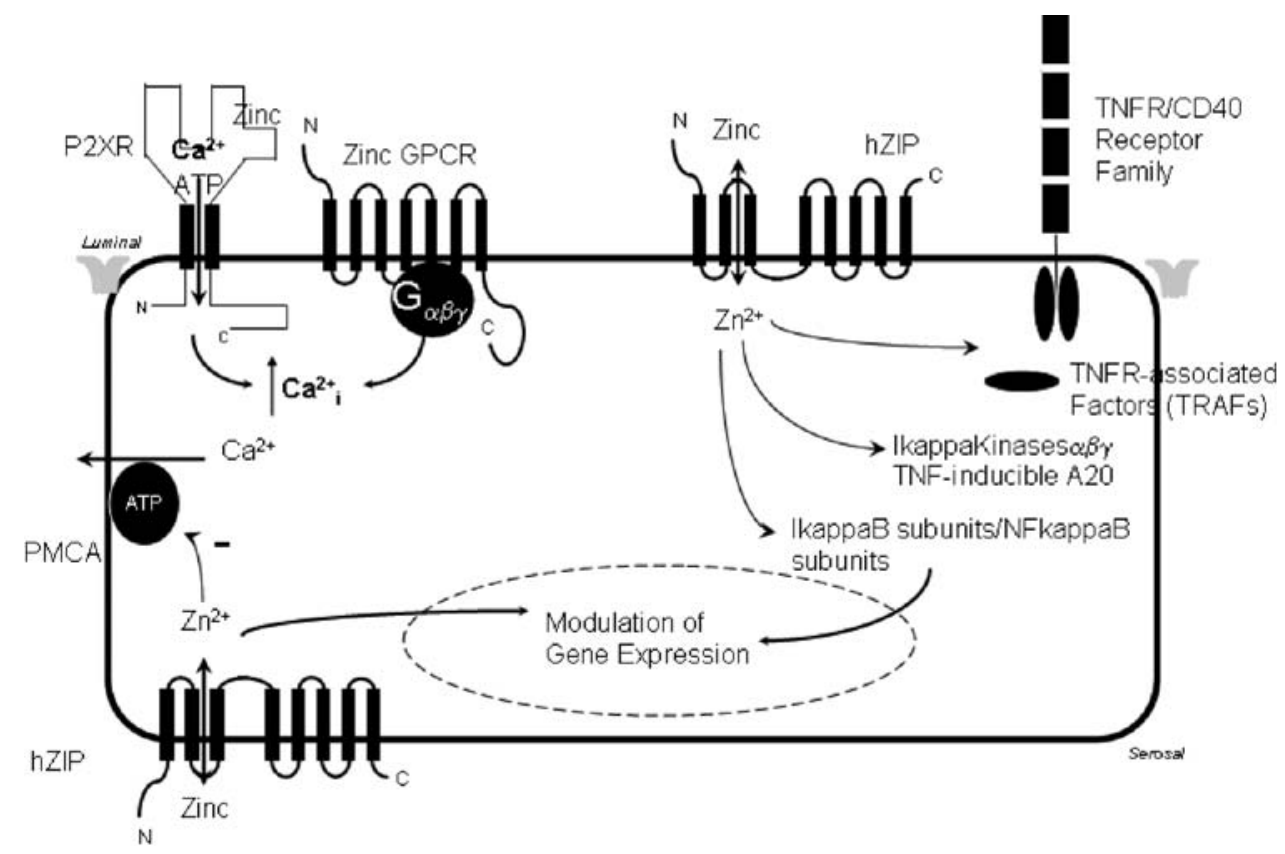

Figure 5. Cellular mechanisms of zinc's anti-inflammatory effects in epithelial cells and other cells? Zinc interactions with membrane receptors may have anti-inflammatory benefits. However, if zinc could gain entry into airway epithelia, it is then free to bind to any and all enzymes that require it as a co-factor. Many effectors within inflammatory signaling cascades have zinc finger motifs. If zinc binding has a net inhibitory effect, then inflammatory signaling could be attenuated. 
mon cold, asthma, allergy, and chronic obstructive pulmonary diseases (COPD). Interestingly, a large percentage of CF patients have zinc deficiency due to malabsorption or, perhaps, other etiologies [63, 64]. Zinc could be antiinflammatory via interactions with multiple receptor subtypes (Figure 5).

Alternatively, if zinc could gain entry into cells, it might affect signaling effector molecules directly (Figure 5). Such entry could occur through Zip influx transporters that specifically transport zinc into cells [65-67]. Many such effector molecules have zinc finger binding motifs. A recent review by Zalewski and colleagues also sheds much light on the biological importance and therapeutic potential of zinc in the lung and airways [68]. They show evidence that labile zinc (that not bound by buffering proteins or enzymes and other proteins for which it serves as a cofactor) is often absorbed by cells and packaged in vesicles (especially, secretory granules) where it may be exocytosed [68]. They estimate that high nanomolar to low micromolar zinc could be present in extracellular fluids under certain physiological conditions, secreted as an agonist itself or co-secreted with other ligands or hormones [68]. We hypothesize currently that zinc may attenuate induction of key inflammatory transcription factors and apoptotic effector proteins by gaining entry into epithelial and other cells. We also hypothesize that zinc itself is an important autocrine and paracrine ligand in the lung and airways and elsewhere (see below). It is our sincere hope that zincbased therapeutic formulations will emerge in the near future to help fight $\mathrm{CF}$ and other respiratory diseases.

Despite the lack of understanding with regard to cellular mechanisms of action, however, zinc salts are being formu- lated in over 10 over-the-counter homeopathic medicines to fight common cold by a multitude of OTC remedy manufacturers [69-71]. The concentrations of zinc salt in these remedies are quite high and may cause harm to olfaction and gustation $[72,73]$. We intend to restrict our putative therapeutic doses in the micromolar range because of these potentially harmful effects. The zinc OTC homeopathics have a range of doses from 5 to $10 \%$ zinc salt which translates into a molar concentration range of $16-50 \mathrm{mM}$ zinc salt. It is not clear why such a high dose is used or if it is even necessary.

\section{Polycystic kidney disease}

We have adopted a similar approach to another prevalent genetic disease, polycystic kidney disease (or PKD). For this disease and for a a family of "failure to secrete" endocrine disorders such as diabetes, an oral delivery of zinc salts may be warranted and this is FDA-approved at significant doses for the copper chelating disorder, Wilson's disease [74-77]. A more direct delivery method could also be contemplated.

Figure 6 illustrates a common thread that occurs in both genetic forms of PKD. A galvanizing feature of the field is the fact that protein products of genes implicated in mouse models and human forms of the diseases cluster on or at the apical central monocilium of ductal epithelia [78-80]. The collecting duct of the nephron is a common site for both genetic forms of PKD, autosomal dominant and autosomal recessive. This organelle was thought to have little function besides a morphological feature that defined one ductal epithelial cell type versus another [81]. However,

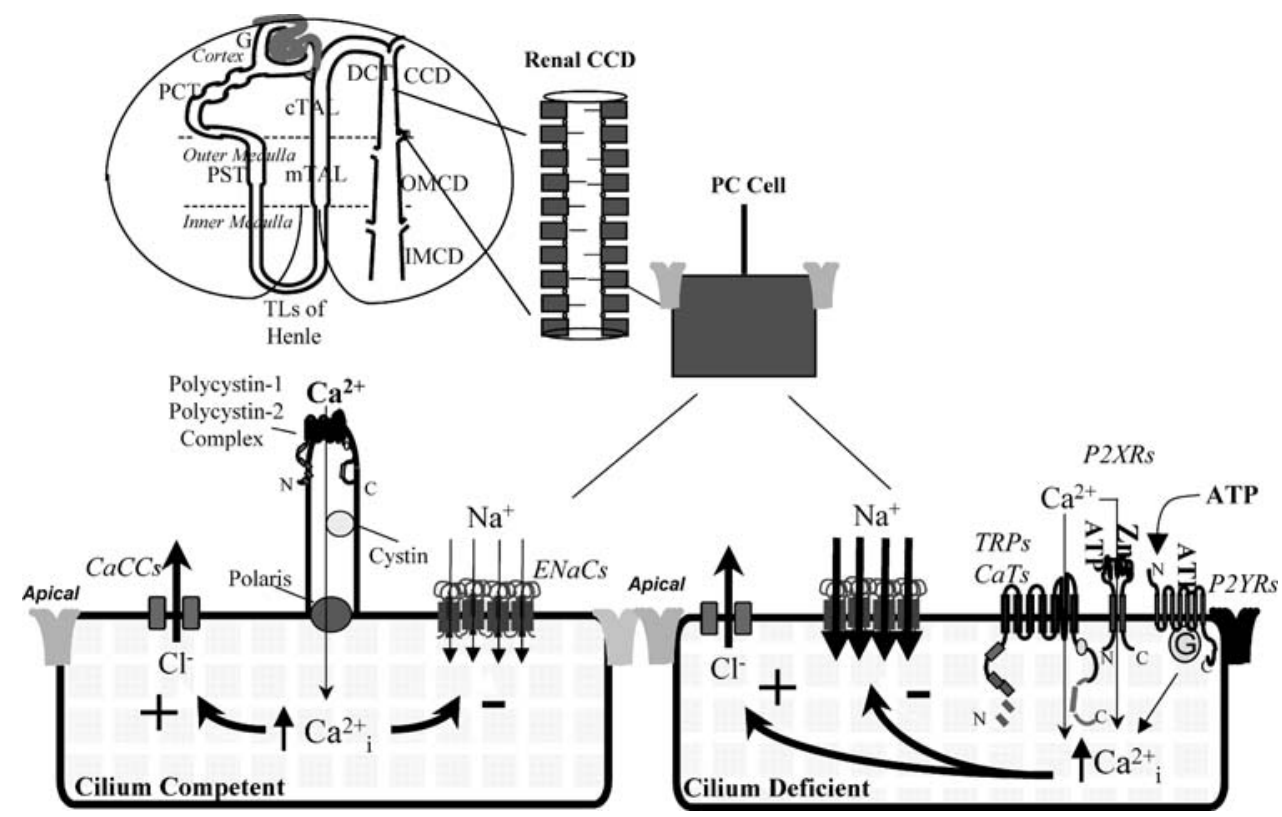

Figure 6. Finding alternative $\mathrm{Ca}^{2+}$ entry mechanisms in ductal epithelia afflicted with polycystic kidney disease: A possible therapeutic benefit? In both genetic forms of PKD, proteins affected by mutation appear to cluster in the apical central monocilium in renal collecting duct epithelia and in ductal epithelia from other tissues. In mouse and human forms of PKD, this cilium is deficient (either abnormal in function or malformed). Apical monocilia have been shown to mediate touch- or flow-induced $\mathrm{Ca}^{2+}$ entry. The latter would be a physiological stimulus for the collecting duct, where tubular fluid flows over it continually. In the absence of a competent monocilium, opening of an alternative $\mathrm{Ca}^{2+}$ entry channel or pathway could recover this ciliumspecific $\mathrm{Ca}^{2+}$ signaling. 
recent work has shown that this organelle, which extends well out beyond the unstirred layer of a duct or tubule, may have sensory functions [82-84]. Principal among these functions is a mechanosensory role [82-86]. Touch or flow across this monocilium in Madin-Darby canine kidney (MDCK) cells triggered a $\mathrm{Ca}^{2+}$ transient that led to a $\mathrm{Ca}^{2+}$ wave within the monolayer of cells [82]. The $\mathrm{Ca}^{2+}$ entry channel involved is likely polycystin-2, a PKD gene product that is a distant member of the transient receptor potential (TRP) $\mathrm{Ca}^{2+}$ entry channel superfamily [87, 88]. Roles for additional TRP channels in this monociliumderived $\mathrm{Ca}^{2+}$ entry have not been ruled out $[89,90]$. It is also possible that the apical or luminal monocilium may also be an osmosensor or a chemosensor for ductal epithelia. Epithelial cells along the duct may need to sense flow as well as sample the fluid flowing through the tubule or duct to ascertain whether the fluids produced are of normal composition.

Figure 6 compares a cilium-competent ductal epithelial cell from the cortical collecting duct of the kidney with a cilium-deficient cell. In the renal collecting duct, the principal cell is the major monociliated cell [81]. In a cilium-deficient cell, cilium-derived $\mathrm{Ca}^{2+}$ signaling is lost. In the face of this and likely other signaling defects, $\mathrm{Na}^{+}$ absorption appears upregulated in cilium-deficient principal cells ([91] and D. Olteanu, B.K. Yoder and E.M. Schwiebert, unpublished observations). Because ENaC channels are tonically active, loss of an inhibitory signal may leave them dysinhibited. Moreover, chronic $\mathrm{Ca}^{2+}$ entry signals may also support many other ductal epithelial cell functions. As such, to curtail hypertension and to correct the lost $\mathrm{Ca}^{2+}$ entry signal, alternative $\mathrm{Ca}^{2+}$ entry channels or pathways must be sought. Figure 6 also shows multiple possible targets for this therapeutic angle. Principal among those are epithelial $\mathrm{P} 2 \mathrm{X}$ receptor chan- nels. The collecting duct luminal chemical microenvironment would be ideal for extracellular zinc and ATP binding and $\mathrm{Ca}^{2+}$ entry, because $\mathrm{Na}^{+}$and $\mathrm{Mg}^{2+}$ are almost completely reabsorbed from the tubular fluid $(5 \%$ or less is left for each cation). As such, our $\mathrm{Ca}^{2+}$ entry Ringer is a close approximation to collecting duct tubular fluid [3, 4, 7], particularly with regard to $\mathrm{Na}^{+}$and $\mathrm{Mg}^{2+}$ concentrations. Both extracellular ligands, zinc and ATP, are freely filtered at the glomerulus and may also be released by flow and other stimuli along the nephron. We hope and believe that this may be a viable primary or adjunct therapy along with administration of the diuretic, amiloride, and the aldosterone antagonist, spironolactone, to fight hypertension in PKD [92] and other renal hypertensive disorders.

\section{"Failure to secrete" endocrine and neuroendocrine disorders}

$\mathrm{Ca}^{2+}$ entry is an essential trigger for exocytosis in all cells. $\mathrm{Ca}^{2+}$ release from intracellular stores is insufficient, especially in immune, endocrine or neuroendocrine cells that function mainly as secretory cells. Secretory cells, in this case, are those whose major function is to release agonist. Figure 7 shows the normal components that are involved in stimulus-secretion coupling in the pancreatic $\beta$ cell in the islets of Langarhans [93-95]. Normally, glucose rises in the plasma after a meal. It is taken up by $\beta$ cells where it triggers new intracellular ATP synthesis. When the ATP/ADP ratio rises, ATP overcomes ADP and inhibits the K(ATP) channel complex. Closure of these tonically active $\mathrm{K}^{+}$channels depolarizes the cell. The $\beta$ cell is an excitable cell, despite the fact it is not morphologically akin to nerve or muscle cells. Voltage-dependent $\mathrm{Ca}^{2+}$ entry channels open in response to the depolarizing

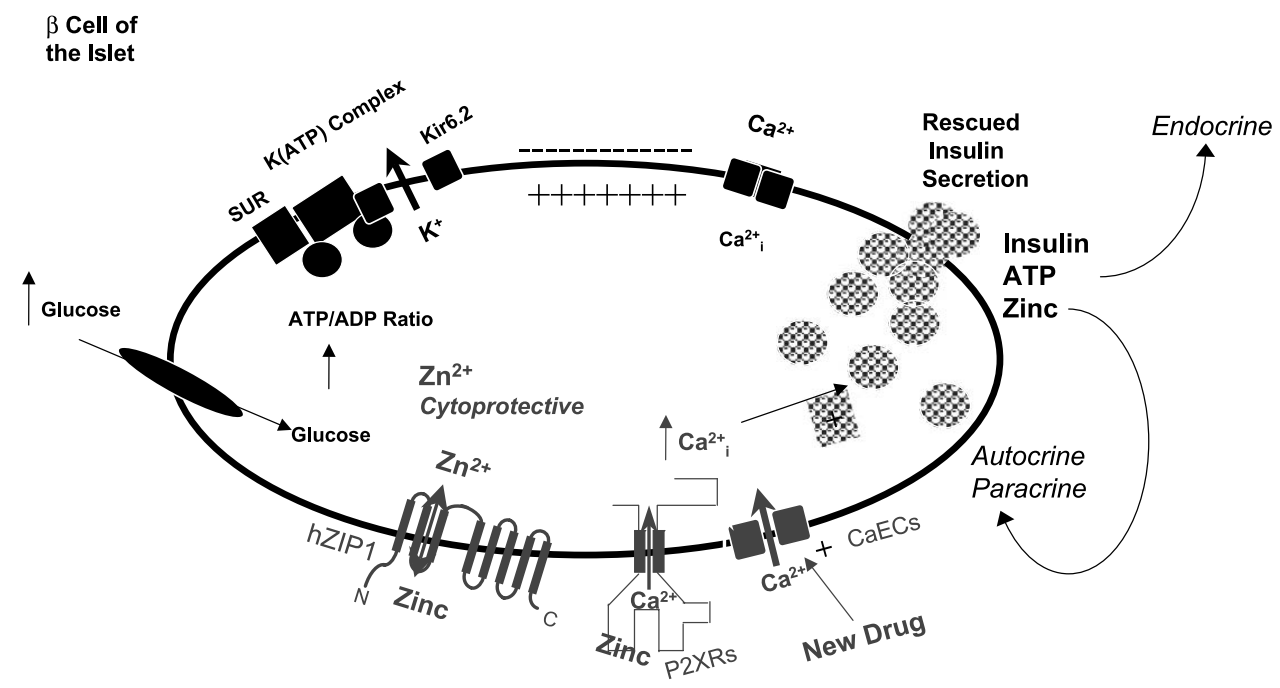

Figure 7. Control of hyperglycemic diabetic syndromes with a zinc-based therapeutic formulation? In the controlled diabetic scenario, by-passing the glucose- and voltage-dependent mechanism of $\mathrm{Ca}^{2+}$ entry and insulin secretion by activating an alternative $\mathrm{Ca}^{2+}$ entry channel pathway (CaEC) could be an important therapeutic modality in diabetes and could re-stimulate insulin secretion. P2XR receptor $\mathrm{Ca}^{2+}$ entry channel may be such a pathway. Such an approach only requires the $\mathrm{Ca}^{2+}$ entry step that would trigger the exocytosis of secretory granules containing insulin, ATP, and zinc. We are interested in the autocrine effects of all three secreted agonists for normal $\beta$ cell physiology. Zinc may also be a cytoprotective for the diabetic $\beta$ cell that is targeted for autoimmune desctruction or some other cellular stress in multiple diabetic states. 
membrane potential. This glucose- and voltage-dependent $\mathrm{Ca}^{2+}$ entry triggers the fusion and release of the contents of insulin secretory granules.

In multiple diabetic and/or hyperglycemic states, pancreatic $\beta$ cells are disabled in their ability to secrete insulin [96] or are reduced in mass and number in the face of autoimmune (type I) or type 2 diabetes-specific insults [96]. Any maneuver to rescue impaired insulin secretion or to maximize the function of remaining $\beta$ cells or transplanted $\beta$ cells in destructive diabetic states might prove helpful to diabetics. Figure 7 also shows these hypothesized therapeutic angles. First, in terms of glucose- and voltage-independent rescue of insulin secretion, a prime target for an alternative $\mathrm{Ca}^{2+}$ entry pathway that is sustained and robust is the extracellular zinc and ATPgated P2X receptor channel. We first thought that this translational physiology might be far-fetched. In reality, an explosion of recent papers has examined zinc deficiency in numerous diabetic and hyperglycemic states [97]. Nutritional experts are examining the importance of adequate zinc intake in gestational diabetes and other forms of diabetes relating to acquired insulin resistance [97]. Moreover, zinc biology is closely coupled to insulin biology. Every commercially available insulin injection for a diabetic has millimolar zinc salt included with the purified insulin polypeptide [55]. Zinc is an essential cofactor for insulin packaging within the secretory granule and insulin multimerization (hexamerization) within the secretory granule [97].

Within the $\beta$ cell, zinc is loaded and packaged with insulin. A particular zinc-specific transporter, $\mathrm{ZnT}$, is only expressed in $\beta$ cells within the pancreatic islet where it loads the insulin-containing secretory granule with this essential cofactor [98]. As such, zinc must be co-released with insulin. The same has been suggested for insulin and ATP [99]. As such, once insulin is released, millimolar quanta of zinc and ATP also appear extracellularly. Although the concentration of each will dilute in the interstitium, we hypothesize that extracellular zinc and ATP are key autocrine and paracrine mediators for the $\beta$ cell in particular and the islet in general. Binding of either or both to $\mathrm{P} 2 \mathrm{X}$ receptor channels may potentiate insulin release in the short term. Extracellular zinc may also be absorbed into the $\beta$ cell cytosol via Zip zinc-specific influx transporters. We speculate that zinc may be cytoprotective for the $\beta$ cell in the cytosol and protect it from autoimmune-, oxidative-, or circulating factor-mediated destruction. This $\beta$ cell biology is a new focus of our laboratory.

\section{Future directions}

We hope that these data, ideas, and interpretations of the literature spawn new sub-fields of purinergic signaling. The idea that the $\mathrm{P} 2 \mathrm{X}$ receptor and channel may also be a sensor is a very simple one. Its topology and that of the $\mathrm{ENaC}$ superfamily is as much reminiscent of a growth factor receptor as an ion channel. The $\mathrm{P} 2 \mathrm{X}$ receptor channel sensor may be one of many proteins that help the cell 'sense' its own external environment. The idea that the $\mathrm{P} 2 \mathrm{X}$ receptor is a cell surface zinc receptor might be more difficult to swallow. However, we predict that parallels and crossover between extracellular ATP release and signaling and extracellular zinc release and signaling will emerge in multiple cell and tissue microenvironments in the coming years.

\section{Acknowledgements}

We are grateful for the support of HL63934 (R01 NIH Grant to EMS) and DK54367 (R01 NIH grant to EMS) for support of our research, hypotheses, and ideas. We acknowledge recent and current support from the Cystic Fibrosis Foundation (to EMS) for our CF work, DK67343 (R01 NIH Grant to EMS) for our polycystic kidney disease work, and UAB intramural funds for our diabetes work. In his new position and affiliation, AZ is supported by a Hungarian Scientific Research Fund (OTKA) Grant (T037524). A full utility patent application has been filed in January 2004 encompassing provisional patent applications, USPTO Serial\# 60/441,045 and USPTO Serial\# $60 / 475,423$, concerning use of zinc at lower micromolar doses delivered to epithelial P2X receptor channel targets for human therapies. The patent with the USPTO is pending. We hold a patent with the European Patent Office for the same full utility patent application, WO2004064742. No licensing agreements have been established to date.

\section{References}

1. Schwiebert EM, Zsembery A. Extracellular ATP as a signaling molecule for epithelial cells. Biochim Biophys Acta 2003; 1615: 7-32.

2. Schwiebert EM, Zsembery A, Geibel JP. Chapter 2. Cellular mechanisms and physiology of nucleotide and nucleoside release from cells: Current knowledge, novel assays to detect purinergic agonists, and future directions. In Schwiebert EM (ed): Extracellular Nucleotides and Nucleosides. Current Topics in Membranes, Volume 54, c2003. San Diego, California: Academic Press 2003.

3. Zsembery A, Boyce AT, Liang L et al. Sustained calcium entry through P2X nucleotide receptor channels in human airway epithelial cells. J Biol Chem 2003; 278: 13398-408.

4. Zsembery A et al. Extracellular zinc and ATP restore chloride secretion across cystic fibrosis airway epithelia by triggering calcium entry. J Biol Chem 2004; 279: 10720-9.

5. Hershfinkel M, Moran A, Grossman N, Sekler I. A zinc-sensing receptor triggers the release of intracellular calcium and regulates ion transport. Proc Natl Acad Sci USA 2001; 98: 11749-54.

6. McNulty TJ, Taylor CW. Extracellular heavy metal ions stimulate calcium mobilization in hepatocytes. Biochem J 1999; 339: 555-61.

7. Liang L, Zsembery A, Schwiebert EM. RNA interference targeted against multiple $\mathrm{P} 2 \mathrm{X}$ receptor subtypes attenuates zinc-induced calcium entry. Am J Physiol 2005; 288(2): C240-52.

8. North RA. Molecular physiology of P2X receptors. Physiol Rev 2002; 82: 1013-67.

9. Kellenberger S, Schild L. Epithelial sodium channel/degenerin 
family of ion channels: A variety of functions for a shared structure. Physiol Rev 2002; 82: 735-67.

10. Benos DJ, Stanton BA. Functional domains within the degenerin epithelial sodium channel (Deg/ENaC) superfamily of ion channels. J Physiol (Lond) 1999; 520: 631-44.

11. Bianchi L, Driscoll M. Protons at the gate: DEG/ENaC ion channels help us feel and remember. Neuron 2002; 34(3): 337-40.

12. Waldmann R. Proton-gated cation channels - neuronal acid sensors in the central and peripheral nervous system. Adv Exp Med Biol 2001; 502: 293-304.

13. Welsh MJ, Price MP, Xie J. Biochemical basis of touch perception: Mechanosensory function of degenerin/epithelial $\mathrm{Na}^{+}$channels. J Biol Chem 2002; 277(4): 2369-72.

14. Ennion SJ, Evans RJ. Conserved cysteine residues in the extracellular loop of the human $\mathrm{P} 2 \mathrm{X}_{1}$ receptor form disulfide bonds and are involved in receptor trafficking to the cell surface. Mol Pharmacol 2002; 61: 303-11.

15. Clyne JD, Wang LF, Hume RI. Mutational analysis of the conserved cysteines of the rat $\mathrm{P} 2 \mathrm{X}_{2}$ purinoceptor. J Neurosci 2002; 22: 3873-80

16. Nagaya N, Tittle RK, Saar $\mathrm{N}$ et al. An intersubunit zinc binding site in rat $\mathrm{P} 2 \mathrm{X}_{2}$ receptors. J Biol Chem 2005; 280(28): 25982-93.

17. Baron $\mathrm{A}$ et al. Zinc and protons are coactivators of acid-sensing ion channels. J Biol Chem 2001; 276(38): 35361-7.

18. Adams CM, Snyder PM, Welsh MJ. Paradoxical stimulation of a DEG/ENaC channel by amiloride. J Biol Chem 1999; 274(22): $15500-4$.

19. Adams CM, Snyder PM, Price MP, Welsh MJ. Protons activate brain $\mathrm{Na}^{+}$channel 1 by inducing a conformational change that exposes a residue associated with neurodegeneration. J Biol Chem 1998; 273(46): 30204-7.

20. Bianchi L et al. The neurotoxic MEC-4(d) DEG/ENaC sodium channel conducts calcium: Implications for necrosis initiation. Nat Neurosci 2004; 7(12): 1337-44

21. Yamamura $\mathrm{H}$, Ugawa $\mathrm{S}$, Ueda $\mathrm{T}$ et al. Protons activate the $\delta$-subunit of the epithelial $\mathrm{Na}^{+}$channel. J Biol Chem 2004; 279: 12529-34.

22. Benos DJ. Sensing tension: Recognizing $\mathrm{ENaC}$ as a stretch sensor. Hypertension 2004; 44(5): 616-7.

23. Tavernarakis N, Driscoll M. Mechanotransduction in Caenorhabditis elegans: The role of $\mathrm{DEG} / \mathrm{ENaC}$ ion channels. Cell Biochem Biophys 2001; 35(1): 1-18.

24. Ji HL, Fuller CM, Benos DJ. Osmotic pressure regulates alpha beta gamma rENaC expressed in Xenopus oocytes. Am J Physiol 1998; 275(5): C1182-90.

25. Kizer N, Guo XL, Hruska K. Reconstitution of stretch-activated cation channels by expression of the alpha subunit of the epithelial sodium channel cloned from osteoblasts. Proc Natl Acad Sci USA 1997; 94(3): 1013-8.

26. Le KT, Babinski K, Seguela P. Central $\mathrm{P} 2 \mathrm{X}_{4}$ and $\mathrm{P} 2 \mathrm{X}_{6}$ channel subunits coassemble into a novel heteromeric ATP receptor. J Neurosci 1998; 18: 7152-9.

27. Torres GE, Egan TM, Voigt MM. Hetero-oligomeric assembly of P2X receptor subunits. J Biol Chem 1999; 274: 6653-9.

28. Jones CA, Vial C, Sellers LA et al. Functional regulation of $\mathrm{P} 2 \mathrm{X}_{6}$ receptors by $\mathrm{N}$-linked glycosylation: Identification of a novel alpha beta-methylene ATP-sensitive phenotype. Mol Pharmacol 2004; 65(4): 979-85.

29. Wiley JS, Dubyak GR. Extracellular adenosine triphosphate increases cation permeability of chronic lymphocytic leukemic lymphocytes. Blood 1989; 73: 1316-25.

30. Pizzo P, Zanovello P, Bronte V, Di Virgilio F. Extracellular ATP causes lysis of mouse thymocytes and activates a plasma membrane ion channel. Biochem J 1991; 274: 139-44.

31. Baricordi OR, Ferrari D, Melchiorri L et al. An ATP-activated channel is involved in mitogenic stimulation of human T lymphocytes. Blood 1996; 87: 682-90.

32. Balzer M, Lintschinger B, Groschner K. Evidence for a role of Trp proteins in the oxidative stress-induced membrane conductances of porcine aortic endothelial cells. Cardiovasc Res 1999; 42: 543-9.

33. Arnon A, Hamlyn JM, Blaustein MP. Sodium entry via store- operated channels modulates calcium signaling in arterial myocytes. Am J Physiol 2000; 278: C163-73.

34. Faurskov B, Bjerregaard HF. Evidence for cadmium mobilization of intracellular calcium through a divalent cation receptor in renal distal epithelial A6 cells. Pflugers Arch 2002; 445(1): 40-50.

35. Hogstrand C, Verbost PM, Wendelaar Bonga SE. Inhibition of human erythrocyte calcium ATPase by zinc. Toxicology 1999; 133(2-3): 139-45.

36. Acuna-Castillo C, Morales B, Huidobro-Toro JP. Zinc and copper modulate differentially the $\mathrm{P} 2 \mathrm{X}_{4}$ receptor. J Neurochem 2000; 74: 1529-37.

37. Kellerman D, Evans R, Mathews D, Shaffer C. Inhaled $\mathrm{P} 2 \mathrm{Y}_{2}$ receptor agonists as a treatment for patients with cystic fibrosis lung disease. Adv Drug Deliv Rev 2002; 54: 1463-74.

38. Cloutier MM, Guernsey L, Sha'afi RI. Duramycin increases intracellular calcium in airway epithelium. Membr Biochem 1993; 10: $107-18$

39. Lansley AB, Sanderson MJ. Regulation of airway ciliary activity by calcium: Simultaneous measurement of beat frequency and intracellular calcium. Biophys J 1999; 77: 629-38.

40. Korngreen A, Ma W, Priel Z, Silberberg SD. Extracellular ATP stimulates directly a cation-selective channel in rabbit airway ciliated epithelial cells. J Physiol 1998; 508: 703-20.

41. Ma W, Korngreen A, Uzlaner $\mathrm{N}$ et al. Extracellular sodium regulates airway ciliary beat motility by inhibiting a $\mathrm{P} 2 \mathrm{X}$ receptor. Nature 1999; 400: 894-7.

42. Amuzescu B, Segal A, Flonta ML et al. Zinc is a voltage-dependent blocker of native and heterologously expressed epithelial sodium channels. Pflugers Arch 2003; 446: 69-77.

43. Sheng S, Perry CJ, Kleyman TR. External nickel inhibits epithelial sodium channels by binding histidine residues within the extracellular domains of alpha and gamma subunits and reducing channel open probability. J Biol Chem 2002; 277: 50098-111.

44. Sheng S, Perry CJ, Kleyman TR. Extracellular zinc activates epithelial $\mathrm{Na}^{+}$channels by eliminating $\mathrm{Na}^{+}$self-inhibition. $\mathrm{J}$ Biol Chem 2004; 279: 31687-96.

45. Sheng S, Burns JB, Kleyman TR. Extracellular histidine residues crucial for $\mathrm{Na}^{+}$self-inhibition of epithelial $\mathrm{Na}^{+}$channels. J Biol Chem 2004; 279: 9743-9.

46. Cucu D, Simaels J, Van Driessche W, Zeiske W. External $\mathrm{Ni}^{2+}$ and $\mathrm{ENaC}$ in A6 cells: $\mathrm{Na}^{+}$current stimulation by competition at a binding site for amiloride and $\mathrm{Na}^{+}$. J Membr Biol 2003; 194(1): $33-45$.

47. O'Grady SM, Lee SY. Chloride and potassium channel function in alveolar epithelial cells. Am J Physiol 2003; 284: L689-700.

48. Devor DC, Singh AK, Frizzell RA, Bridges RJ. Modulation of $\mathrm{Cl}^{-}$ secretion by benzimidazolones: I. Direct activation of a calciumactivated $\mathrm{K}^{+}$channel. Am J Physiol 1996; 271: L775-84.

49. Frindt G, Palmer LG. Apical potassium channels in the rat connecting tubule. Am J Physiol 2004; 287: F1030-7.

50. Wei Y, Chen YJ, Li D et al. Dual effect of insulin-like growth factor on the apical 70-pS channel in the thick ascending limb of rat kidney. Am J Physiol 2004; 286: C1258-63.

51. Satlin LM. Developmental regulation of expression of renal potassium secretory channels. Curr Opin Nephrol Hypertens 2004; 13: $445-50$.

52. Joiner WJ, Basavappa S, Vidyasagar $\mathrm{S}$ et al. Active $\mathrm{K}^{+}$secretion through multiple $\mathrm{K}_{\mathrm{Ca}}$-type channels and regulation of $\mathrm{IK}_{\mathrm{Ca}}$ channels in rat proximal colon. Am J Physiol 2003; 285: G185-96.

53. Truong-Tran AQ, Carter J, Ruffin R, Zalewski PD. New insights into the role of zinc in the respiratory epithelium. Immunol Cell Biol 2001; 79: 170-7.

54. Novick G, Godfrey JC, Pollack RL, Wilder HR. Zinc-induced suppression of inflammation in the respiratory tract, caused by infection with human rhinovirus and other irritants. Med Hypotheses 1997; 49: 347-57.

55. WWW Reference: www.accessdata.fda.gov/scripts/cder/drugsatfda.

56. Berg K, Bolt G, Anderson H, Owen TC. Zinc potentiates the antiviral action of human IFN-alpha tenfold. J Interferon Cytokine Res 2001; 21: 471-4. 
57. Cho YH, Lee SJ, Kim SW et al. Antibacterial effect of intraprostatic zinc injection in a rat model of chronic bacterial prostatitis. Int J Antimicrob Agents 2002; 19: 576-82.

58. Moran J, Addy M, Corry D et al. A study to assess the plaque inhibitory action of a new zinc citrate toothpaste. J Clin Periodontol 2001; 28: 157-61.

59. WWW Reference: Higdon J. The Linus Pauling Institute's Micronutrient Information Center: Subject: Zinc, 1-12, 2003.

60. Walker CF, Black RE. Zinc and the risk for infectious disease. Annu Rev Nutr 2004; 24: 255-75.

61. Truong-Tran AQ, Ruffin RE, Zalewski PD. Visualization of labile zinc and its role in apoptosis of primary airway epithelial cells and cell lines. Am J Physiol 2000; 279(6): L1172-83.

62. Schwiebert EM, Guggino WB. Abnormal chloride and sodium channel function in cystic fibrosis airway epithelia. In Crystal RG, West JB et al. (eds): Chapter 195 for The Lung: Scientific Foundations. Philadelphia: Lippincott-Raven 1996.

63. Krebs NF, Westcott JE, Arnold TD et al. Abnormalities in zinc homeostasis in young infants with cystic fibrosis. Pediatr Res 2000; 48: 256-61.

64. Mazzocchi C, Michel JL, Chalencon V et al. Zinc deficiency in mucoviscidosis. Arch Pediatr 2000; 7: 1081-4.

65. Wang K, Zhou B, Kup Y-M et al. A novel member of the zinc transporter family is defective in acrodermatitis enteropathica. Am J Hum Genet 2002; 7: 66-73.

66. Duffner-Beattie J, Wang F, Kuo Y-M et al. The acrodermatitis enteropathica gene ZIP4 encodes a tissue-specific, zinc-regulated zinc transporter in mice. J Biol Chem 2003; 278: 13398-408.

67. Eide D. The SLC39 family of metal ion transporters. Pflugers Arch 2003; 447(5): 796-800.

68. Zalewski PD, Troung-Tran AQ, Grosser D et al. Zinc metabolism in airway epithelium and airway inflammation: Basic mechanisms and clinical targets. A review. Pharmacol Ther 2005; 105: 127-49.

69. Hirt M, Nobel S, Barron E. Zinc nasal gel for the treatment of common cold symptoms: A double-blind, placebo-controlled trial. Ear Nose Throat J 2000; 79: 778-82.

70. Mossad SB, Macknin ML, Medendorp SV, Mason P. Zinc gluconate lozenges for treating the common cold. A randomized, doubleblind, placebo-controlled study. Ann Intern Med 1996; 125: 81-8.

71. Mossad SB. Effect of zincum gluconicum nasal gel on the duration and symptom severity of the common cold in otherwise healthy adults. QJM 2003; 96: 35-43.

72. McBride K, Slotnick B, Margolis FL. Does intranasal application of zinc sulfate produce anosmia in the mouse? An olfactometric and anatomical study. Chem Senses 2003; 28: 659-70.

73. Jafek BW, Linschoten MR, Murrow BW. Anosmia after intranasal zinc gluconate use. Am J Rhinol 2004; 18: 137-41.

74. Brewer GJ. Treatment of Wilson's disease with zinc. J Lab Clin Med 1999; 134: 322-4.

75. Brewer GJ, Dick RD, Johnson VD et al. Treatment of Wilson's disease with zinc XVI. Treatment through the pediatric years. J Lab Clin Med 2001; 137: 191-8.

76. Najda J, Stella-Holowiecka B, Machalski M. Low-dose zinc administration as an effective Wilson's disease treatment. Biol Trace Elem Res 2001; 80: 281-4.

77. Farinati F, Cardin R, D'inca R et al. Zinc treatment prevents lipid peroxidation and increases glutathione availability in Wilson's disease. J Lab Clin Med 2003; 141: 372-7.
78. Yoder BK, Hou X, Guay-Woodford LM. The polycystic kidney disease proteins polycystin-1, polycystin-2, Polaris, and cystin are colocalized in renal cilia. J Am Soc Nephrol 2002; 13(10): 2508-16.

79. Yoder BK, Tousson A, Millican L et al. Polaris, a protein disrupted in orpk mutant mice, is required for assembly of renal cilium. Am J Physiol 2002; 282: F541-52.

80. Guay-Woodford LM. Murine models of polycystic kidney disease: Molecular and therapeutic insights. Am J Physiol 2003; 285: F1034-49.

81. Madsen KM, Tisher CC. Structural-functional relationship along the distal nephron. Am J Physiol 1986; 250: F1-15.

82. Praetorius HA, Spring KR. Bending the MDCK primary cilium increases intracellular calcium. J Membr Biol 2001; 184: 71-9.

83. Praetorius HA, Spring KR. Removal of the MDCK primary cilium abolishes flow sensing. J Membr Biol 2003; 191: 69-76.

84. Nauli SM et al. Polycystins 1 and 2 mediate mechanosensation in the primary cilium of kidney cells. Nat Genet 2003; 33(2): 129-37.

85. Pazour GJ, Rosenbaum JL. Intraflagellar transport and ciliadependent diseases. Trends Cell Biol 2002; 12(12): 551-5.

86. Haycraft CJ, Swoboda P, Taulman PD et al. The C. elegans homolog of the murine cystic kidney disease gene $\operatorname{Tg} 737$ functions in a ciliogenic pathways and is disrupted in $O S M-5$ mutant worms. Development 2001; 128: 1493-505.

87. Hanaoka K, Qian F, Boletta A et al. Co-assembly of polycystin-1 and polycystin-2 produces unique cation-permeable currents. Nature 2000; 408(6815): 990-4.

88. Koulen P, Cai Y, Geng L et al. Polycystin-2 is an intracellular calcium release channel. Nat Cell Biol 2002; 4(3): 191-7.

89. Chen $\mathrm{XZ}$ et al. Polycystin-L is a calcium-regulated cation channel permeable to calcium ions. Nature 1999; 401(6751): 383-6.

90. Liu Y, Li Q, Tan M et al. Modulation of the human polycystin-L channel by voltage and divalent cations. FEBS Lett 2002; 525(1-3): 71-6.

91. Rohatgi R, Greenberg A, Burrow CR et al. Sodium transport in autosomal recessive polycystic kidney disease (ARPKD) cyst-lining epithelial cells. J Am Soc Nephrol 2003; 14(4): 827-36.

92. Guay-Woodford LM, Desmond RA. Autosomal recessive polycystic kidney disease: The clinical experience in North America. Pediatrics 2003; 111(5): 1072-80.

93. Ackerman MJ, Clapham DE. Ion channels - basic science and clinical disease. N Engl J Med 1997; 336: 1575-86.

94. Aguilar-Bryan L, Bryan J, Nakazaki M. Of mice and men: K(ATP) channels and insulin secretion. Recent Prog Horm Res 2001; 56: 47-68.

95. Howell SL, Tyhurst M. Insulin secretion: The effector system. Experientia 1984; 40: 1098.

96. Rhodes CJ. Type 2 diabetes - a matter of beta cell life and death? Science 2005; 307: 380-4.

97. Chausner AB. Zinc, insulin, and diabetes. J Am Coll Nutr 1998; 17: 109-15.

98. Liuzzi JP, Cousins RJ. Mammalian zinc transporters. Annu Rev Nutr 2004; 24: 151-72.

99. Hazama A, Hayashi S, Okada Y. Cell surface measurements of ATP release from single pancreatic beta cells using a novel biosensor technique. Pflugers Arch 1998; 437: 31-5.

100. Taylor AL, Kudlow BA, Marrs KL et al. Bioluminescence detection of ATP release mechanisms in epithelia. Am J Physiol 1998; 275: C1391-406. 